\title{
The Implementation of Strategic Management Concepts in Developing the International Reputation of Higher Education
}

\author{
Agustinus Purna Irawan ${ }^{1,2 *}$ Sarwo E. Handoyo ${ }^{1}$ Paula Tjatoerwidya Anggarina ${ }^{3}$ \\ Albertus R. Danendra ${ }^{4}$
}

${ }^{1}$ Master of Management, Universitas Tarumanagara, Jakarta, Indonesia

${ }^{2}$ Faculty of Engineering, Universitas Tarumanagara, Jakarta, Indonesia

${ }^{3}$ Faculty of Economics and Business, Universitas Tarumanagara, Jakarta, Indonesia

${ }^{4}$ Faculty of Medicine, Universitas Indonesia, Jakarta, Indonesia

*Corresponding author.Email: agustinus@untar.ac.id

\begin{abstract}
The reputation of higher education at the international level is one of the work programs of various universities in Indonesia to achieve. Various problems can arise when building this reputation, such as problems with human resources, research and publication skills, students' ability to interact with foreign students, networking, and effective cooperation that can be implemented by universities. This paper aims to discuss strategic management concepts that have been implemented in universities to start building an international reputation. The analytical method used is descriptive analysis and case studies of various activities that have been carried out at Universitas Tarumanagara (Untar). Based on the results of the analysis that has been carried out, the results show that the implementation of strategic management concepts starting from planning, implementing, and evaluating international reputation building activities has been carried out well at Untar and resulted in various achievements such as QS rating, QS Ranking, QS online learning, and ISO 9001: 2015. Various activities such as international student exchanges, holding international conferences, and visiting professors are an important part of building an international reputation. Vision and mission adapted to current needs and future predictions are important things that can drive the achievement of an international reputation. These findings will become one of the references in future developments.
\end{abstract}

Keywords: international reputation, strategic management implementation

\section{INTRODUCTION}

Management and development of a well-planned organization are indispensable for achieving high performance and a good reputation. A good reputation in the eyes of consumers, stakeholders and competitors will generate trust in the company. At the same time, the company can continue to get income and the opportunity to grow bigger and get an increase in mutual welfare. This also applies to tertiary institutions, especially private universities, which are highly dependent on the funds collected from students, other sources, and public trust in these tertiary institutions [1-3].

The management of higher education in Indonesia follows various regulations that have been made by the Ministry of Education and other relevant ministries. Higher education institutions must be able to adjust and implement these various regulations, so that they can continue to grow and develop into reputable universities, both at the national and international levels. Various reputation measures have been established by the Ministry of Education, such as accreditation of universities both nationally and internationally, ranking of universities both nationally and internationally, outputs of research results, publications and innovations by students and lecturers, the development program of the The Threefold Missions of Higher Education (Tri Dharma Perguruan Tinggi) and various other policies. Currently, universities in Indonesia must also carry out independent learning programs and independent campuses, which consist of 3 main groups, namely the quality of students, the quality of lecturers, and the quality of the curriculum [4].

Various regulations in the management of this higher education, must be implemented properly, planned, the implementation of internal and external quality management. In this case, it is necessary to implement strategic management in the management of higher education, so that all provisions, work programs and 
reputation enhancement programs can be implemented in a comprehensive, holistic, and sustainable manner. Strategic management is the art and science of arranging, implementing, and evaluating cross-functional decisions that can enable an organization to achieve its goals. The process in strategic management includes setting organizational goals, developing policies and planning to achieve these goals, and allocating resources to implement policies and plan for achieving organizational goals. In this case, there needs to be a cross-functional combination within the organization to produce the achievement of the overall goals of the organization into an inseparable unit. Therefore, strategic management provides overall direction for the organization and is closely related to the field of organizational behavior. Strategic management must be able to provide the foundation and guidance in decision making in a sustainable organization and be able to adapt responsively to the changes needed according to current and future conditions [5-9]. In general, the implementation of strategic management in higher education management can follow the following model:

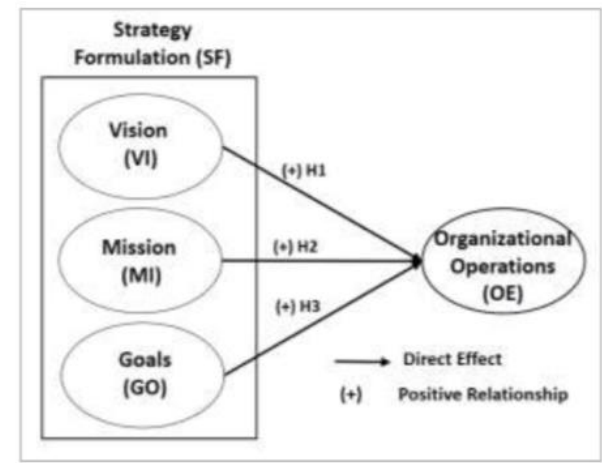

Figure 1. Organizational management model to achieve reputation [5]

This paper discusses the implementation of strategic management in tertiary institutions with a case study at Universitas Tarumanagara (Untar). Untar as one of the oldest, largest, and best private universities in Indonesia, always strives to gain reputation in various fields, both national and international levels. Various strategic policies that have been implemented at Untar have been able to produce various achievements that have been beneficial for the academic community and all other stakeholders. The discussion is limited to how to formulate strategic policies implemented at Untar and the results that Untar can achieve in enhancing its reputation as one of the best private universities in Indonesia.

\section{METHOD}

The application of basic principles in strategic management at private universities has a pattern that nationally follows the national standards of higher education, referring to the Regulation of the Minister of Education and Culture Number 3 of 2020 (Permendikbud No. 3 Tahun 2020). In its implementation, private universities formulate operational policies in accordance with the vision, mission, goals, objectives, and the advantages that each university wants to achieve. The discussion in this paper includes discussion of policy formulation, implementation process flow, and examples of success cases that can be obtained. Discussion with descriptive methods and analysis of the results obtained from the implementation of strategic management at Untar and comparing with the basic principles of strategic management and other relevant references. The flow of thought in writing this paper is shown in Figure 2.

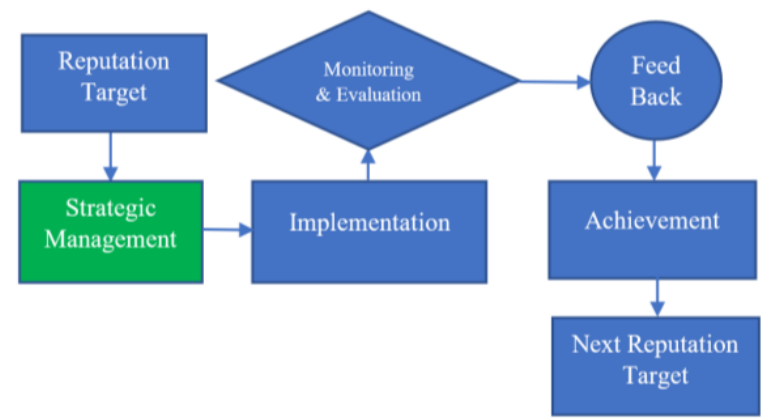

Figure 2. Thinking framework of strategic management implementation

\section{RESULT AND DISCUSSION}

The Ministry of Education and Culture has issued regulations on national standards for higher education. This regulation regulates how universities in Indonesia carry out The Threefold Missions of Higher Education (Tri Dharma Perguruan Tinggi) activities through various standards that must be implemented. National standards must become a reference for every tertiary institution in Indonesia in carrying out learning, research, and community service activities. Higher education institutions must arrange internal implementing regulations that refer to these Ministerial regulations, so that they can be implemented in a more detailed and measured manner. However, not all tertiary institutions can implement all these higher education national standards perfectly. There are still universities that are only able to implement the national higher education standards to only some standards, while other standards are being continuously strived to implement.

Referring to Wheelen and Hunger (2021), organizational goals are the final product of activities planned and decided by the organization, including the following: profitability, efficiency, growth, shareholder wealth, resource utilization, reputation, contributions to employees, contributions to society, market leadership, technology leadership, survival, top management personal needs [6].

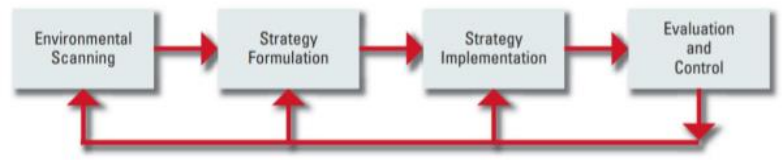

Figure 3. Basic Elements of the Strategic Management Process by Wheelen and Hunger [6] 
Activities carried out by the organization begin with observing and analyzing the organization's environment, formulating strategies for achieving the desired goals, formulating implementation strategies, evaluating, and controlling implementation to match the objectives to be achieved (Figure 3).

Like other organizations, universities also strive to achieve the goals described by Wheelen and Hunger. A private university must be able to manage all the resources it has to carry out learning, research, and community service activities with good quality, but must still be able to pay for all its activities themselves. Private universities must also be able to plan the sustainability of their programs well in the future. Therefore, the implementation of strategic management is very much needed by private universities and must be carried out with a good priority scale to remain efficient and effective to achieve the reputation and trust of the public.

Regarding the basic principles of managing a private university, it must pay attention to efficiency and effectiveness, which are related to the limited resources owned, both human resources, money, supporting facilities and infrastructure, and cooperation partners. A private university must be able to compile a good work team, a good decision-making system, a flexible organizational system, the involvement of human resources including lecturers, employees and students, so that they can achieve organizational performance in accordance with the vision, mission, goals, and objectives to be achieved together (Figure 4).

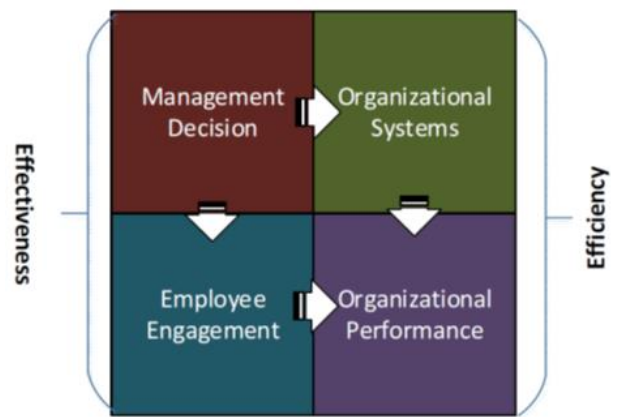

Figure 4. Implementation of the concept of efficiency and effectiveness in organizations [7]

Another thing that needs to be considered in implementing strategic management to achieve organizational goals is organizational culture. Organizational culture influences the way company management collects information and analyzes the internal and external environment. Information obtained from both internal and external is very necessary to identify the strengths, weaknesses, opportunities, and threats that may be faced and need to be responded to immediately. Organizational culture will influence the formal procedures that must be developed, the involvement of all stakeholders, the use of resources, and the performance that can be achieved. Organizations that apply cultural values and norms that are open to their environment will produce a company perspective that tends to see the external environment more broadly and tends to be more flexible in dealing with changes that occur [10-14]. The values and norms held by the company in this case also influence the company's procedures in managing and using the available resources. Organizational culture also affects the way the company views the events that occur within the company. Organizational culture will influence company employees in seeing, assessing, and responding to various events. Good values and norms can underlie every individual in the organization to behave and think positively. A positive response will make it easier for the organization to implement a predetermined achievement strategy. In the end, organizational culture greatly influences organizational strategy to achieve the vision, missions, goals, and objectives to be achieved [10], [15-18]. In this case, the strategies that have been planned and the implementation strategies follow the pattern shown in Figure 5. Based on Figure 5, organizations in implementing strategy planning and execution strategies can choose which ones are in accordance with the conditions of the organization. Although all organizations basically want to be winners, organizations may not reach the final goal of becoming winners, but they are still dreamers because of the inefficiency in running various programs. Therefore, the implementation of strategic management is very necessary to provide confidence that the organization can run according to the goals that have been set and achieve the final goal of becoming a winner [7].

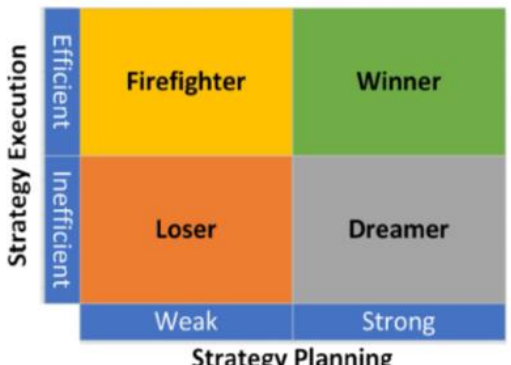

Figure 5. Strategy matrix to become a winning organization [7]

In this case study, Universitas Tarumanagara (Untar) is used as an example of strategic management implementation in enhancing the reputation of a private university. Untar continues to strive to carry out various activities to achieve the national standard of higher education properly. In strategic management, Untar starts all activities based on the vision, missions, goals, and objectives that have been compiled and become a common reference for all academicians in carrying out various activities of the Tri Dharma Perguruan Tinggi. The vision, missions, goals, and objectives that have been set are directed to achieve mutually agreed values, namely: Integrity, Professionalism, and Entrepreneurship. In general, the process flow can be described in Figure 6.

Based on the flow of the Figure 6 process above, the strategy is then outlined in real activities carried out in synergy between lecturers, students, employees, and 
partners both at home and abroad. Various activities carried out to realize Untar's vision and missions are equipped with various supporting regulations that can be referred to by all Untar academicians. This becomes a strategic policy unit, namely the fulfilment of various targets and reputation according to government regulations, to produce a good reputation.

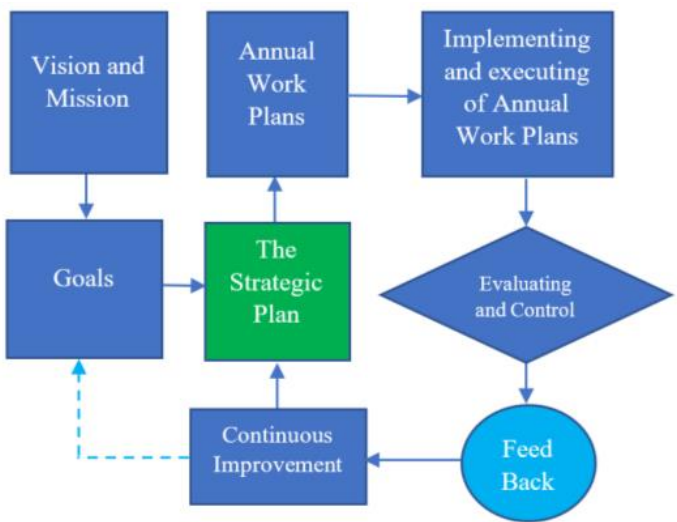

Figure 6. Example of the implementation process flow of strategic management in achieving organizational goals

Some of the reputation achievements that have been achieved by Untar as a result of strategic management implementation include: accreditation of higher education institutions, accreditation of study programs, increase in the national ranking of universities in Indonesia, increase in the rank of private universities in Indonesia, acquisition of QS Rating, acquisition of QS Ranking Asia, acquisition of QS Rating online Learning, acquisition of an independent research cluster, acquisition of MURI award for several achievements, becoming a member of the Asian University Union (AU +), holding various International Conference activities such as TICATE, TICASH, ICASTE, ICEBSH, ICEBM, national student exchange activities and international, national seminars, accredited national journal publications and various other reputational achievements, both for lecturers and students. In terms of the number of students, Untar continues to gain the trust of the public and other stakeholders, so that the number of students is stable. The implementation of strategic management at Untar also monitors the internal quality assurance system and internal audit. The results of monitoring and evaluation are discussed periodically in leadership meetings which are held every month and monitoring meetings for each work program. Some of Untar's achievements can be seen in Figure 7.

\section{CONCLUSION}

The application of strategic management in building the reputation of the organization, including universities, is very important to be implemented properly. Strategic management can help organizational leaders to design the achievement of the organization's reputation starting from establishing a vision, missions, goals, objectives, and strategic plans to achieve predetermined goals. In its implementation, strategic management must be supported by good resources, involvement of all stakeholders, organizational culture, a reliable monitoring and evaluation system, and the ability to adapt quickly to changes that occur externally [10-14]. This also applies to private universities, where operational policies must be drawn up in accordance with the vision, mission, goals, objectives, and advantages to be achieved. Improved reputation and organizational performance can be achieved by implementing good strategic management and monitoring and evaluation systems. A good reputation and performance will generate the trust of the public and all stakeholders, so that the organization can continue to progress and develop into a top organization [15-18].
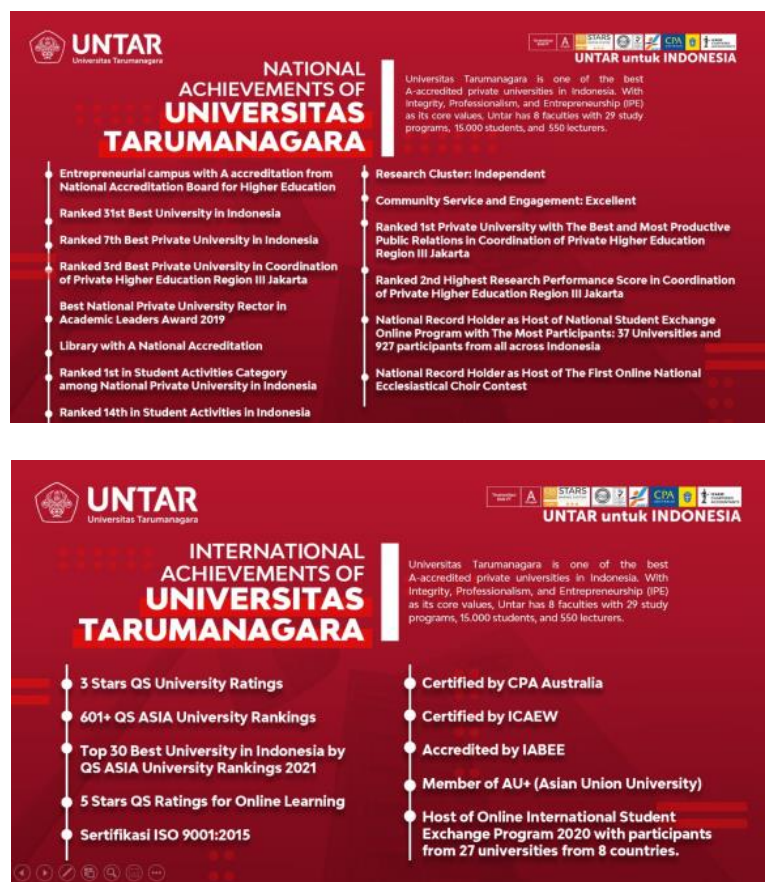

Figure 7. Some examples of the results of strategic management implementation at Untar

\section{REFERENCES}

[1] Fransina Wattimena, Implementasi Strategi Pengembangan Sumber Daya Manusia Dan Dukungan Organisasi Terhadap Peningkatan Kualitas Dosen Fakultas Ekonomi Universitas Pattimura Ambon, Jurnal Manajemen Dan Kewirausahaan, Vol.12, No. 2, September 2010, pp. 195-208.

[2] Nuryadi Wijiharjono, Perkembangan Manajemen Strategik Dalam Perspektif Teoritis Dan Analisis Empiris, Jurnal Akuntansi Vol. 2, No. 2, Februari 2013, pp. 115-128. 
[3] Yunus Winoto, Julian Abdillah, Ute Lies Siti Khadijah, Manajemen Strategis Dalam Pengembangan Program Konsorsium E-Journal oleh FPPTI Jawa Barat, Jurnal Pustaka Budaya, Vol. 7, No. 2. Juli 2020, pp. 5665.

[4] Peraturan Menteri Pendidikan Dan Kebudayaan Republik Indonesia Nomor 3 Tahun 2020 Tentang Standar Nasional Pendidikan Tinggi.

[5] Fahad Al Dhaheri, Ali Ameen, Osama Isaac, The Influence of Strategy Formulation (Vision, Mission, and Goals) on the Organizational Operations, Journal of Critical Reviews, Vol. 7, Issue 17, 2020, pp. 1932-1941.

[6] Thomas L. Wheelen, J. David Hunger, Strategic Management and Business Policy, Pearson Education, Inc, 2012.

[7] Abdullah H. Alharthy, Hamad Rashid Romano, Pagliari Faisal Khan, Identification of Strategy Implementation Influencing Factors and Their Effects on the Performance, International Journal of Business and Social Science Vol. 8, No. 1, January 2017, pp. 34-44.

[8] Chaneta, I., Strategic Management Process, Journal of Comprehensive Research, Vol. 5, Page 17-25.

[9] Saleh A., A. Tamimi, Samihah Khalil, Haim Hilman Abdullah, Applications of Strategic Management Practices in Public Sector: Cases from Some Middle East Countries, Advances in Social Sciences Research Journal, Vol. 5, No. 9, Sep 2018, pp. 36-51.

[10] Muksin Wijaya, Manajemen Stratejik Dan Budaya Perusahaan: Dampak Serta Implementasi, Media Informatika Vol.16 No. 2, 2017, pp. 195-207.

[11] Khalidiya Mostafa Atta Abd, Sami Ahmed Abbas, Araden Hatim Khudair, Impact of Strategic Management Practices on Organizational Entrepreneurship: Mediating Effect of Strategic Intelligence, Academy of Strategic Management Journal, Vol. 18, No. 4, 2019, pp. $1-8$.

[12] Tonderai Nyamwanza, A Case Study Review of the Strategy Formulation and Implementation Link among SMES in Zimbabwe, European Journal of Business and Management, Vol. 5, No. 31, 2013, pp. 138-145.

[13] Chris van Wyk, B. G. Moeng, The Design and Implementation of a Strategic Plan in Primary Schools, International Business \& Economics Research Journal, Vol. 13, No. 1, January/February 2014, pp. 137-144.

[14] Daryosh Mohammadi Janaki, Mohamadali Sobhanallahi, Mehdi Mohammadi Janaki, Identifying the implementation barriers of strategic management using factor analysis and TOPSIS Technique, International Journal of Academic Research in Business and Social Sciences, Vol. 5, No. 11, Nov 2015, pp. 323336.

[15] Emerson Wagner Mainardes, João J. Ferreira, Mário L. Raposo, Strategy and Strategic Management Concepts: Are They Recognised by Management Students? Business Administration and Management, Vol. 17, No. 1, 2014, pp. 43-61.

[16] Mas Bambang Baroto, Nader Arvand, Fauziah Sh. Ahmad, Effective Strategy Implementation, Journal of Advanced Management Science, Vol. 2, No. 1, March 2014, pp. 50-54.

[17] Felicia Anggraini, I Putu Gde Sukaatmadja, Implementasi Strategi Kemitraan, Diferensiasi, dan Layanan Untuk Meningkatan Kinerja Industri Kuliner di Kota Denpasar, E-Jurnal Manajemen UNUD, Vol. 4, No. 11, 2015, 3991-4018.

[18] Agustin Sukarsono, Manajemen Strategik Pengembangan Pemasaran Koperasi Dalam Era Global, Journal Knowledge Industrial Engineering, Vol. 4, No. 1 (2017), pp. 54-62. 